\title{
From Cultural Case Studies to Global Conversations:
}

\author{
Towards an Interconnected Community \\ of Enquiry in Public History
}

Alix R. Green

Collaborative historical meaning making flourishes where its craftspeople assemble around a shared endeavor. This mostly (although not inevitably) involves coming together in person. Indeed, the public history project often derives, and asserts, its identity and its integrity through ties to the particular and the personal. It is bounded by and bonded to a locality, an institution, or a community. Of course, these characterizations are problematic-the question of who belongs has no selfevident answer-but once negotiated, such demarcations provide a certain clarity and sense of purpose for the project and its participants. ${ }^{1}$ Through their professional networks and associations, public historians share the stories of these projects and the lessons about method and practice learned during the process.

Communities of enquiry, facilitated by conferences and journals, form around themes and questions that connect individual case studies (the future of contested heritage sites, for example, or the representation of colonial exploitation in museums). It is only relatively recently, however, that concerted efforts have been made to develop higher-level frameworks-comparative, methodological, conceptual and so on-to help us orient the specific and the local within larger arguments and intellectual concerns. The growing interest in international perspectives on public history is to be welcomed as a vital dimension of these efforts. We are gaining new access to discussions of method and practice in other countries, insights that are most productive when they prompt critical, self-conscious reflection on historical inquiry in the broadest sense-including the powerful politics of historical representation in the world today.

Nießer and Tomann offer a valuable contribution to this emerging literature from outside the Anglophone ambit, and I offer the reflections that follow in

I See for example Fiona Cosson, "Voice of the Community? Reflections on Accessing, Working with and Representing Communities," Oral History 38, no. 2 (Autumn 2010): 95-10I.

THE PUBLIC HISTORIAN, Vol. 40, No. 4, pp. 56-60 (November 20I8). ISSN: 0272-3433, electronic ISSN 1533-8576. (C) 2018 by The Regents of the University of California and the National Council on Public History. All rights reserved. Please direct all requests for permission to photocopy or reproduce article content through the University of California Press's Reprints and Permissions web page, http://www.ucpress.edu/journals.php?p=reprints. DOI: https://doi.org/Io.I525/tph.20I8.40.4.56. 
a mode of engaged dialogue rather than close critique. The article identifies the "two 'stakeholders' of the discipline of history in Germany," as academic historians and scholars of Geschichtsdidaktik (historical didactics, or history education). Public and applied history are emerging at the tectonic boundary between these two intellectual plates, an interface that has both generative and abrasive qualities. That these specialties are in close enough contact to be "in friction" is a notable insight for historians practicing in the academic cultures of other countries. ${ }^{2}$ The shared departmental roof strikes me as significant. It signals that the formulation of historical knowledge and the cultivation of historical understanding and reasoning fall under the auspices of one discipline-that they constitute a collective endeavor, even if tensions characterize the division of labor.

In the UK, there are rather different contexts and drivers for public history. One is an external funding agenda that is incentivizing academics to achieve "impact" for their research; here, public history provides a language to bring narrative coherence to activities designed to "engage" the public with historical research. Laura King and Gary Rivett have noted the problematic "soft paternalism" often involved, which may instrumentalize the engagement process in ways that remain underexplored. ${ }^{3}$ Public history can offer a framework for integrating engagement into the research process itself, although there are imbalances here too, to which I return later. The distinctions between "pure" research and the work of "sharing" history with public audiences may be blurring in the UK, but they remain persistently in view. For me, this makes understanding the organizational infrastructures (and organizational politics) of history in countries such as Germany and then seeking to place the different insights within larger frameworks such valuable tasks.

Yet in seeking to create more productive cross-border communities of enquiry in public history, we are often starting with a marked intellectual disadvantage. It is striking that public historians, broadly understood, have not taken as keen a critical interest in our own professional pasts as our scholarly training might promise. To take the longer view is not merely an academic exercise, however. It reveals a more extensive intellectual root system than the conventional "child of the r97os" accounts suggest. Robert Kelley's I978 article, "Public History: Its Origins, Nature, and Prospects,"4 (to take an obvious example) is often treated outside the United States as a foundational text. To do so-indeed to ascribe to any document such a statustends to preclude the critical handling historians prize as a core disciplinary value.

This "young earth" conception of public history creates a too neat bifurcation between "academic" and "public" careers, serving to narrow what is potentially

2 Jacqueline Nießer and Juliane Tomann, "Public and Applied History in Germany: Just Another Brick in the Wall of the Academic Ivory Tower?" The Public Historian 40, no. 4 (November 2018): II-27, quotations II.

3 Laura King and Gary Rivett, "Engaging People in Making History: Impact, Public Engagement and the World Beyond the Campus," History Workshop Journal 80, no. I (October 2015): 223.

4 Robert Kelley, "Public History: Its Origins, Nature, and Prospects," The Public Historian I, no. I (Autumn 1978), I9. 
a richly shaded set of historical practices into some kind of employability pathway. Nießer and Tomann's article rehearses this familiar history, reflecting their reliance on Simone Rauthe's Public History in den USA und der Bundesrepublik Deutschland. ${ }^{5}$ Absent is the longer history of applied history in the United States, most notably Rebecca Conard's work on Benjamin Shambaugh (1871-I940, professor of political science at the University of Iowa and head of the State Historical Society of Iowa). Shambaugh introduced the term "applied history" in I909, which he defined as the "use of the scientific knowledge of history and experience in efforts to solve present problems of human betterment." He regarded applied history education as a legitimate function of public universities, drawing an equivalence between the training it provided for public service with that of lawyers, doctors and engineers. ${ }^{6}$ John Tosh has shown how the "decisive period in the emergence of a critical public history in Britain was between the mid-I86os and the late I930s."7 For Shambaugh, as for British historians such as John Robert Seeley (1834-1895, first Regius Professor of History at the University of Cambridge), "applying" history was "doing" history. The latter's maxim that history "should not merely gratify the reader's curiosity about the past, but modify his view of the present and his forecast of the future" anticipates Jörn Rüsen's formulation by almost a century. ${ }^{8}$

I am sure we would all agree, as historians, that history matters; this history should matter to us in particular, because recognizing more nuanced, more historically attuned lineages of public history shifts our perspective on the present-day field in fundamental ways. The implication is we cannot proceed from the premise that public history is (just) a recent American phenomenon to which university systems around the world are responding. In terms of intellectual heritage, public history and the "established historical sciences" have more in common than divides them. Public historians are currently attending to what seems distinctive to the field as it has developed in their countries or regions; less consideration has been given to exploring the conceptual and methodological issues that would advance our understanding of the shared ideas and concerns underpinning the work of what I have called "history with public purpose." Cultural case studies are essential if we are to

5 Simone Rauthe, Public History in Den USA Und Der Bundesrepublik Deutschland (Essen: Klartext, 200I).

6 Rebecca Conard, Benjamin Shambaugh and the Intellectual Foundations of Public History (Iowa City: University of Iowa Press, 2002), 33-4; 83.

7 John Tosh, "Public History, Civic Engagement and the Historical Profession in Britain," History 99, no. 335 (April 2014), 198.

8 John Robert Seeley, The Expansion of England: Two Courses of Lectures, 2nd ed. (London: Macmillan, I895), I; Jörn Rüsen, "The Didactics of History in West Germany: Towards a New SelfAwareness of Historical Studies," History and Theory 26, no. 3 (October I, 1987): 285. Rüsen argues: "If we can consider historical education as an intentional and organized process of identity formation that remembers the past in order to understand the present and anticipate the future, then the didactics of history can no longer be dismissed as being extraneous to the concerns of professional historians." Emphasis mine.

9 Alix R. Green, History, Policy and Public Purpose: Historians and Historical Thinking in Government (London: Palgrave Macmillan UK, 20I6). 
develop a "map" of the global field, but they can be developed alongside and in dialogue with efforts to gain a critical purchase on the "big questions" with which we all must engage. Public and applied history are interdisciplinary enterprises, as Nießer and Tomann rightly emphasize; here, conversations with other fields that developed "public" fields of enquiry around the same time as history-such as philosophy, sociology, geography, anthropology and archaeology-would help us refine and respond to those big questions. ${ }^{10}$

Seeking greater interplay between the conceptual and the cultural strands of enquiry into public history might suggest new ways to view the apparent tensions and problems with which the field is contending. For example, Nießer and Tomann describe the two Centers for Applied History in Germany-in Bavaria and Frankfurt (Oder) - as divided by an apparent schism: "one makes money, the other makes citizens." 11 The perceived disjuncture between these two missions can be explained by reference to the context of higher education in Germany and of the German historical sciences in particular. But there are other layers to the explanation we may wish to consider. That there is a clear and meaningful distinction within public history-between what could be characterized as client-oriented/ commercially driven and public-oriented/community-driven activity-appears to be something of a self-evident truth. It is reassuring to think that what we do is beneficial and benevolent, and so fundamentally different from work in settings (such as commercial ones) where those imperatives are less easily identified and troublesome matters of money and power are closer to the surface.

Yet, if self-criticality is essential to the public history mind-set, what happens when we inspect such assumptions, and bring in conceptual and comparative perspectives? Public history has certainly been nourished by the emergence of social history and a concern to value perspectives "from below." It is a lineage that has been particularly influential in the UK and inspired creative-and creatively disruptive-projects, often working against the gradient of power. A corollary of this agenda has been a reluctance to consider groups deemed powerful, policymakers for example, as legitimate partners for the kind of collaborative historical endeavor that is celebrated when done elsewhere (museums, charities, local heritage societies, and so on).

We cannot make judgments about particular approaches to or settings for public/history by applying, if unconsciously, some measure of their inherent "virtue." Being alert to and open about our preferences and choices in allocating our attention-and willing to address the tensions and inconsistencies that

Io See for example Noam Chomsky, "Philosophers and Public Philosophy," Ethics 79, no. I (October 1968): I-9; Alfred McClung Lee, "Presidential Address: Sociology for Whom?," American Sociological Review 4I, no. 6 (December 1976): 925-36; Louise Lamphere, "The Convergence of Applied, Practicing, and Public Anthropology in the 2Ist Century," Human Organization 63, no. 4 (Winter 2004): 43I-43; Joe Smith, "Geography in Public and Public Geography: Past, Present and Future," The Geographical Journal I79, no. 2 (June 2013): I88-92.

II Nießer and Tomann, "Public and Applied History in Germany," I7. 
inevitably arise from them-are part of our "duty of discontent." 12 Problems can arise even when we feel that a piece of work is fully aligned with our professional and personal commitments. As D. J. Sherman has noted, public history projects can affirm identity and agency in communities, but they also confirm the authority and the social utility of the historian as professional-a potentially insidious step. ${ }^{13}$ Once it is within historians' purview to share the authority to make history then they can also elect to withhold it; the difference between "sharing authority" and "a shared authority" is not merely one of grammatical nuance. ${ }^{14}$

My point is that we should approach the tasking of mapping the global field with constructive skepticism and self-awareness. "All people writing about public and applied history are part of the phenomenon they describe," Nießer and Tomann argue; yes, indeed, and so any constructions and categorizations we form within the field that involve selective allocation of our attention and approbation need careful critical inspection. ${ }^{15}$ Actively engaging with international networks and embracing both cultural and conceptual modes of enquiry should allow us to fulfill our duty of discontent in productive and creative ways.

Alix R. Green is lecturer in history at the University of Essex. She read history at the University of Cambridge, and spent ten years in policy research and government relations before gaining her doctorate at the University of Hertfordshire. She brings her experience outside higher education to her current work on contemporary political history and the uses of history in public life. Her book, History, Policy and Public Purpose: Historians and Historical Thinking in Government, was published by Palgrave Macmillan in 2oI6. She is currently working on a co-designed project with the John Lewis Partnership Heritage Centre and Archive on the company's historical approach to pay. She is the founding convenor of the Public History Seminar at the Institute of Historical Research, London, and a Fellow of the Royal Historical Society. She is currently serving as the Society's Honorary Co-Director of Communications and as a juror on its Public History Prize committee.

I2 Keith Jenkins, Sue Morgan, and Alun Munslow, eds., Manifestos for History (London: Routledge, 2007), I. See also Ludmilla Jordanova, History in Practice, 2nd ed. (London: Hodder Arnold, 2006), I.

I3 D. J. Sherman, "Objects of Memory: History and Narrative in French War Museums," French Historical Studies 19, no. I (Spring 1995): 49-74.

I4 Michael Frisch, 'Public History Is Not a One-Way Street,' or from a Shared Authority to the City of Mosaics, and Back," (Keynote address, International Federation for Public History conference, Ravenna, Italy, June 7, 20I7). "The message seems to be that sharing authority is a Good Thing ... In contrast, 'A Shared Authority', suggests something that 'is' .. . [T] he interpretive process and the meaning-making process ... are already shared, by definition." See also "From a Shared Authority to the Digital Kitchen, and Back," in Letting Go?: Sharing Historical Authority in a UserGenerated World, ed. Bill Adair, Benjamin Filene, and Laura Koloski (Philadelphia: Pew Center for Arts \& Heritage, 2012).

I5 Nießer and Juliane Tomann, "Public and Applied History in Germany," II. 